\title{
23. PRELIMINARY INVESTIGATION OF THE PETROGRAPHY AND GEOCHEMISTRY OF LIMESTONES AT LIMALOK AND WODEJEBATO GUYOTS (SITES 871 AND 874), REPUBLIC OF THE MARSHALL ISLANDS ${ }^{1}$
}

\author{
Jennifer L. Wyatt, ${ }^{2}$ Terrence M. Quinn, ${ }^{2}$ and Gareth R. Davies ${ }^{3}$
}

\begin{abstract}
Drilling at Limalok (Site 871) and Wodejebato (Site 874) guyots, Republic of the Marshall Islands, during Ocean Drilling Program Leg 144, revealed that $\sim 289$ and $\sim 163 \mathrm{~m}$ of shallow-water limestones overlie volcanic substrate at these sites, respectively. Hole $871 \mathrm{C}$ was drilled in the central lagoon at Limalok at a water depth of $1255 \mathrm{~m}$, whereas Hole $874 \mathrm{~B}$ was drilled on an inner perimeter ridge at Wodejebato at a water depth of $1374 \mathrm{~m}$. Shipboard biostratigraphy indicates that neritic limestones from Hole 87IC are late Paleocene to middle Eocene, whereas limestones from Hole 874B are Maastrichtian.

We have combined petrography and isotope geochemistry $\left(\delta^{18} \mathrm{O}, \delta^{13} \mathrm{C},{ }^{87} \mathrm{Sr} /{ }^{86} \mathrm{Sr}\right)$ to constrain the diagenetic histories of these two guyots. Carbonates from Holes $871 \mathrm{C}$ and $874 \mathrm{~B}$ primarily consist of grainstones, packstones, and wackestones that exhibit moldic and vuggy porosity. Hole $871 \mathrm{C}$ samples are moderately well cemented with equant, microspar calcite. Cements in Hole $874 \mathrm{~B}$ carbonates are generally coarser and more abundant, primarily with prismatic and radiaxial equant to bladed forms. The vast majority of Hole 871C samples are non-cathodoluminescent, whereas Hole 874B samples from $\sim 116$ to $163 \mathrm{mbsf}$ display dull to bright cathodoluminescence.

Oxygen and carbon isotope values of matrix and cement samples from Hole $871 \mathrm{C}$ range from $-5.28 \%$ to $0.50 \%$ and $-0.68 \%$ to $2.33 \%$, respectively. Most samples from Hole $874 \mathrm{~B}$ have $\delta^{18} \mathrm{O}$ values that cluster between $-1.97 \%$ and $-0.20 \%$; however, six bivalve samples have lower $\delta^{18} \mathrm{O}$ values ranging from $-4.34 \%$ to $-3.07 \%$. The $\delta^{13} \mathrm{C}$ values of carbonates from Hole $874 \mathrm{~B}$ range from $0.92 \%$ to $3.13 \%$. Depleted oxygen isotope values (less than $-3 \%$ ) are consistent with diagenetic alteration with meteoric water at low water/rock ratios.

Sr-isotope ratios from Hole 871C samples are consistent with an early Paleogene age; however, the temporal resolution of seawater $\mathrm{Sr}$ isotopes is minimal during this time. For Hole 874B, strontium-isotope analyses of 36 samples indicate that the ${ }^{87} \mathrm{Sr} /{ }^{86} \mathrm{Sr}$ ratio varies from $0.707869 \pm 0.000009$ (Maastrichtian, $\sim 67 \mathrm{Ma}$ ) near the top of the sequence to $0.707730 \pm 0.000012$ (latest Campanian, $\sim 72 \mathrm{Ma}$ ) near the base. The Campanian/Maastrichtian boundary is most likely between 136.66 and 143.66 mbsf, based upon $\mathrm{Sr}$ isotopes.
\end{abstract}

\section{INTRODUCTION}

Shallow-water reefal carbonates have the potential to record multiple episodes of diagenetic alteration, because of their proximity to the sea surface and to waters of varying chemistry. Previous studies of Pacific Ocean atolls have examined various diagenetic alteration products in an attempt to constrain the origins of fluids that have affected these carbonates (e.g., Major and Matthews, 1983; Aissaoui et al., 1986; Saller and Moore, 1989, 1991). The nature of the altering fluids can be discerned from geochemical and petrographic signatures recorded in the mineralogy and texture of shallow-water carbonates by means of an integrated analytical approach using stable isotopes $\left(\delta^{18} \mathrm{O}\right.$ and $\left.\delta^{13} \mathrm{C}\right)$ within a well-constrained stratigraphic and petrographic framework (e.g., Land, 1970; Matthews, 1974; Allan and Matthews, 1982; Budd 1988a, 1988b; Lohmann, 1988; Budd and Land, 1990).

Evidence for fresh-water alteration of platform carbonates has been used to constrain the extent of atoll emergence resulting from past sea-level fluctuations (e.g., Major and Matthews, 1983; Ludwig et al., 1988). Located in a mid-plate tectonic setting, atolls and guyots can serve as an independent check and calibration tool for sea-level trends predicted from stable continental margins (e.g., Schlanger and Premoli Silva, 1986; Lincoln and Schlanger, 1991).

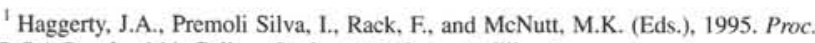
ODP, Sci. Results, 144: College Station, TX (Ocean Drilling Program).

${ }^{2}$ Department of Geology, University of South Florida, Tampa, FL 33620-5200, U.S.A

${ }^{3}$ Faculty of Earth Sciences, Vrije Universiteit, Amsterdam, The Netherlands.
Petrographic features (e.g., cement morphology, porosity type) are useful in the study of the processes of meteoric diagenesis (e.g., Dunham, 1971; Longman, 1980; Budd, 1988a). However, because similar features may form in a variety of diagenetic environments (e.g., Wilkinson et al., 1985), textural observations must be combined with geochemical data to constrain the diagenetic history of a carbonate sequence accurately (e.g., Budd, 1988a; Budd and Land, 1990; Quinn, 1991). Isotopically, calcitization in the meteoric environment tends to produce stratigraphically homogenous $\delta^{18} \mathrm{O}$ values and variable $\delta^{13} \mathrm{C}$ values that become progressively greater with depth away from the subaerial exposure surface (Allan and Matthews, 1982; Lohmann, 1988). Meteoric calcitization is easily recognized because fresh-water oxygen isotope values are distinctly depleted relative to marine values. Hence, petrographic and geochemical data used in concert provide strong evidence for the origin of diagenetic alteration in carbonates.

Sr isotopes have been used successfully to date the deposition and diagenesis of Cenozoic neritic carbonates (e.g., Swart et al., 1987; Ludwig et al., 1988; Vahrenkamp et al., 1988; Saller and Koepnick, 1990; Quinn et al., 1991; Ohde and Elderfield, 1992). The premise behind using $\mathrm{Sr}$ isotopes as a chronostratigraphic tool is that the seawater ${ }^{87} \mathrm{Sr} /{ }^{86} \mathrm{Sr}$ ratio at the time of deposition is preserved in, or can be deciphered from (Richter and DePaolo, 1988), the measured ${ }^{87} \mathrm{Sr} /{ }^{86} \mathrm{Sr}$ ratio of the sample. Because fresh-water alteration may cause a stratigraphic redistribution of strontium (Quinn et al., 1991), stable-isotope evidence of meteoric alteration, such as low $\delta^{13} \mathrm{C}$ values and water-dominated $\delta^{18} \mathrm{O}$ values, can be used to identify altered Sr-isotope values (e.g., Quinn et al., 1991).

The objective of this study is to determine the diagenetic histories of Limalok and Wodejebato guyots (Sites 871 and 874, respectively), documenting any evidence of meteoric alteration that would indicate 
atoll emergence. Such a study is a prerequisite to any future interpretations of the sea-level histories of these guyots.

\section{GEOLOGIC SETTING}

Limalok (formerly Harrie) Guyot is located in the Ratak Chain of the southern Marshall Islands in the western equatorial Pacific Ocean (see site map preceding title page). Limalok is considered to be the youngest drowned platform of this region (early Paleogene), and it shares its volcanic pedestal with Mili Atoll to the northwest. Although its present position is $5.6^{\circ} \mathrm{N}, 172.4^{\circ} \mathrm{E}$, paleomagnetic analyses of the volcanic substrate indicate that Limalok formed at $\sim 10^{\circ} \mathrm{S}$ (Premoli Silva, Haggerty, Rack, et al., 1993). Site 871 is located in the south central portion of Limalok Guyot $\left(5^{\circ} 33.43^{\prime} \mathrm{N}, 172^{\circ} 20.66^{\prime} \mathrm{E}\right)$ at a water depth of $1255 \mathrm{~m}$. Of the three holes drilled in the lagoon area, only Hole 871C penetrated the limestone platform, from 133.7 to 422.9 meters below seafloor (mbsf). Core recovery was exceptionally low, averaging 3.5\% (Premoli Silva, Haggerty, Rack, et al., 1993).

Wodejebato (formerly Sylvania) Guyot is located in the northernmost portion of the Ralik Chain of the Marshall Islands; it is attached to Pikinni Atoll to the southeast (see site map preceding title page). Wodejebato formed at a southerly latitude during the Late Cretaceous and has since drifted to $12.0^{\circ} \mathrm{N}, 164.9^{\circ} \mathrm{E}$. Four volcanic ridges radiate from the central edifice, and two perimeter ridges parallel the summit edge (Bergersen, 1993). Site 874 is located on the northeastern portion of Wodejebato Guyot $\left(12^{\circ} 00.76^{\prime} \mathrm{N}, 164^{\circ} 55.22^{\prime} \mathrm{E}\right)$, within the inner perimeter ridge, at a water depth of $1374 \mathrm{~m}$. Because of drilling difficulties, only $\sim 1.5 \mathrm{~m}$ of shallow-water carbonates was recovered from Hole 874A. However, a second attempt (Hole 874B) recovered a discontinuous sequence of limestones from 0.11 to $162.82 \mathrm{mbsf}$. An average core recovery of $19.7 \%$ was reduced to $16.7 \%$ on account of the low core recovery from 86.2 to $116.8 \mathrm{mbsf}(<1.6 \%)$.

\section{PREVIOUS WORK}

Before the Ocean Drilling Program (ODP) drilling in this area, interpretations of guyot stratigraphy were based upon dredge hauls, side-scan imagery, and seismic lines (Limalok: Schlanger et al., 1987; Wodejebato: Schlanger and Duennebier, 1988; Bergersen, 1993). From these studies, both structures were interpreted as showing the classic guyot pattern of a pelagic cap overlying lagoon sediments, perimeter reef rims, and gullied lower slopes consisting of debris flows (Schlanger et al., 1987). The two perimeter ridges that parallel the summit of Wodejebato were interpreted to represent two episodes of reef building (Bergersen, 1993).

Limestones dredged from Limalok were assigned an early Eocene age, based upon the planktonic foraminifer biostratigraphy (Schlanger et al., 1987). However, ODP cores recovered late Paleocene fauna at the base of the carbonate sequence, indicating earlier reef growth. Because of the presence of middle early Eocene limestone clasts intermingled with planktonic foraminifers and basalt clasts, Schlanger et al. (1987) suggested that the volcanic platform and its "embryonic fringing reef" were exposed and eroded during this time, thus allowing shallow-marine carbonates to be deposited at depth. They correlated this period of apparent emergence with the $150-\mathrm{m}$ drop in sea level reported by Haq et al. (1987) during the latest early Eocene.

Because of low platform-carbonate recovery (average 3.5\%), a precise reconstruction of the depositional and diagenetic histories of Limalok Guyot is difficult. The sequence at Limalok displays a generally shallowing-upward trend, with depositional environments ranging from open subtidal (latest Paleocene) to shallow lagoon (early to middle Eocene; Premoli Silva, Haggerty, Rack, et al., 1993). Shipboard lithostratigraphic analysis found no unequivocal evidence of subaerial exposure and concomitant fresh-water diagenesis of these limestones (Premoli Silva, Haggerty, Rack, et al., 1993).

Dredged carbonates from Wodejebato consist of a Campanian to Maastrichtian shallow-water reefal assemblage, as well as poorly pre- served shell fragments and whole specimens of Albian rudists (Lincoln et al., 1993). The presence of mid and Late Cretaceous fauna, coupled with evidence for multiple episodes of mid-plate tectonic activity during this time, led Lincoln (1990) to suggest that two distinct reef-building events occurred upon Wodejebato. Combining this hypothesis with additional geomorphic information, Bergersen (1993) proposed that the initial Albian reef was exposed and eroded by tectonic uplift and restricted volcanic activity across the edifice, and this erosional surface was later capped by a Late Cretaceous reef caused by tectonic quiescence and platform subsidence.

Drilling by ODP personnel recovered a late Campanian to Maastrichtian sequence of neritic carbonates at Wodejebato; no Albian fossils have been reported from any of the five holes drilled during Leg 144. The only evidence thus far for a pre-Campanian history for this guyot is the presence of rare Cenomanian nannofossils found reworked within basal clays in Hole 877 (Premoli Silva, Haggerty, Rack, et al., 1993). Recent ${ }^{40} \mathrm{Ar} /{ }^{39} \mathrm{Ar}$ dating of the volcanic platform has provided ages of $82-85$ Ma for Wodejebato (G.R. Davies, pers. comm., 1994). Although dredged limestones and seismic profiles have not provided unequivocal evidence of karst development upon Wodejebato, ODP shipboard lithostratigraphic analyses indicate that the diagenetic history of Wodejebato may have been complex because of the presence of strong cementation, moldic porosity, and reddish brown material that infills solution cavities (Premoli Silva, Haggerty, Rack, et al., 1993).

\section{METHODS}

A set of 45 borehole samples from Hole $871 \mathrm{C}$ and 40 samples from Holes $874 \mathrm{~A}$ and $874 \mathrm{~B}$ was cut into thin sections and petrographically described. Porosity abundance was visually determined using a modified porosity comparison chart after Terry and Chilingar (1955), and cements were described according to Folk's classification scheme (1965). Cathodoluminescence analysis was performed using a MAAS/ Nuclide Luminoscope (ELM-3 Series) mounted on an Olympus BH2 petrographic microscope. Operating conditions consist of an accelerating voltage of 10 to $13 \mathrm{kV}$, a beam current of 0.5 to $0.8 \mathrm{~mA}$, and a beam focus of $\sim 5 \mathrm{~mm}$.

Powdered samples $(<1.0 \mathrm{mg})$ of skeletal allochems, rock matrix, and calcite cement were extracted from polished thin-section billets using a microscope-mounted drill assembly. Before stable-isotope analyses were conducted at the University of Michigan, the powders were roasted for $1 \mathrm{hr}$ at $380^{\circ} \mathrm{C}$ to remove volatile contaminants. Samples were reacted with anhydrous phosphoric acid at $75^{\circ} \mathrm{C}$ in individual reaction vessels of a CarboKiel carbonate extraction system coupled to the inlet of a Finnegan MAT 251 mass spectrometer. Precision $( \pm 1 \sigma)$ for stable isotope analysis was $<0.08 \%$, and all isotope values are reported in standard $\delta$ notation relative to the Chicago PDB standard.

Strontium was separated using $\mathrm{SrSpec}^{\mathrm{TM}}$ ion-exchange column chemistry and loaded on rhenium single filaments with tantalum fluoride and phosphoric acid. Samples were analyzed using the Finnegan MAT 261 multicollector mass spectrometer by way of a triple-collector double-jump routine at the Vrjie Universiteit, Amsterdam. Over the course of our study, 18 analyses of NBS-987 yielded a mean of $0.710272 \pm 0.000014$ ( $2 \sigma$ mean), which compares well with the longterm laboratory average of $0.710269 \pm 0.000017(2 \sigma$ mean; $N=69)$.

\section{RESULTS \\ Limalok (Site 871)}

The neritic carbonate interval in Hole $871 \mathrm{C}$ extends from 133.7 to 422.9 mbsf. Lithologically, Hole $871 \mathrm{C}$ limestones consist of skeletal grainstones, packstones, wackestones, and rare mudstones (Table 1). The upper $60 \mathrm{~m}$ ( 134-194 mbsf) consists of interbedded packstones and grainstones, and is overlain by a 1-cm-thick iron-manganese and phosphatic crust that contains planktonic foraminifers within borings. 
Table 1. Oxygen, carbon and strontium isotopic compositions of selected samples from Holes 871C, 874A, and 874B.

\begin{tabular}{|c|c|c|c|c|c|c|c|}
\hline $\begin{array}{l}\text { Core, section. } \\
\text { interval }(\mathrm{cm})\end{array}$ & $\begin{array}{l}\text { Depth } \\
\text { (mbsf) }\end{array}$ & ST & $\begin{array}{c}\delta^{18} \mathrm{O} \\
(\mathrm{PDB})\end{array}$ & $\begin{array}{l}\delta^{13} \mathrm{C} \\
(\mathrm{PDB})\end{array}$ & ${ }^{87} \mathrm{Sr} /{ }^{86} \mathrm{Sr}$ & $\pm 2 \sigma$ & $\mathrm{RN}$ \\
\hline \multicolumn{8}{|l|}{ 144-871C. } \\
\hline $2 \mathrm{R}-\mathrm{I}, 0-6$ & 133.70 & & & & & & w \\
\hline $2 \mathrm{R}-1,7-10$ & 133.77 & $\mathrm{x}$ & -1.73 & 1.29 & 0.707916 & 0.000011 & $\mathrm{p}$ \\
\hline $2 \mathrm{R}-1,27-32$ & 133.97 & $\mathrm{x}$ & -5.28 & 0.74 & & & p \\
\hline $2 \mathrm{R}-\mathrm{I}, 54-58$ & 134.24 & $\mathrm{x}$ & -5.25 & 1.19 & & & $\mathrm{~g}$ \\
\hline $2 \mathrm{R}-1,59-63$ & 134.29 & $\mathrm{x}$ & -4.95 & 1.19 & & & $\mathrm{~g}$ \\
\hline $3 R-1,10-18$ & 143.40 & $\mathrm{x}$ & 0.50 & 1.78 & & & $\mathrm{p}$ \\
\hline $4 \mathrm{R}-1,24-28$ & 153.14 & $\mathrm{x}$ & 0.33 & 1.88 & 0.707894 & 0.000010 & $\mathrm{p}$ \\
\hline $4 \mathrm{R}-\mathrm{I}, 42-44$ & 153.32 & c & -1.73 & 1.19 & & & $g$ \\
\hline $4 \mathrm{R}-1,42-44$ & 153.32 & c & -1.62 & 1.31 & & & \\
\hline $4 \mathrm{R}-1,52-55$ & 153.42 & & & & & & g \\
\hline $5 \mathrm{R}-1,4-7$ & 162.64 & $\mathrm{x}$ & -0.61 & 1.39 & & & $\mathrm{~g}$ \\
\hline $5 \mathrm{R}-1,4-7$ & 162.64 & c & -0.21 & 1.62 & & & \\
\hline $6 \mathrm{R}-1,4-10$ & 172.34 & $\mathrm{x}$ & -4.17 & 0.86 & & & $\mathrm{p}$ \\
\hline $6 \mathrm{R}-1,24-29$ & 172.54 & $x$ & -1.53 & 0.91 & 0.707860 & 0.000013 & $\mathrm{~g}$ \\
\hline $7 R-1,0-4$ & 181.90 & & & & & & $\mathrm{p}$ \\
\hline $8 R-1,3-6$ & 191.53 & $\mathrm{x}$ & -1.98 & 0.87 & & & w \\
\hline $8 \mathrm{R}-1,20-25$ & 491.70 & $x$ & -4.57 & 1.29 & 0.707824 & 0.000007 & $w$ \\
\hline $8 \mathrm{R}-1,20-25$ & 191.70 & $\mathrm{x}$ & -4.78 & 1.10 & & & \\
\hline $9 \mathrm{R}-1,23-30$ & 201.43 & $\mathrm{x}$ & -5.01 & 0.82 & & & $\mathrm{~m}$ \\
\hline $10 \mathrm{R}-1,14-19$ & 211.04 & $\mathrm{x}$ & 0.14 & 1.48 & 0.707896 & 0.000009 & w \\
\hline $11 \mathrm{R}-1,0-6$ & 220.50 & $x$ & -0.95 & 1.25 & & & $\mathrm{~g}$ \\
\hline $12 \mathrm{R}-1,4-9$ & 230.14 & $\mathrm{x}$ & -2.09 & 1.17 & & & $\mathrm{~m}$ \\
\hline $13 \mathrm{R}-1,10-14$ & 239.90 & $\mathrm{x}$ & -1.39 & 1.13 & 0.707899 & 0.000012 & $\mathrm{p}$ \\
\hline $14 \mathrm{R}-1,16-22$ & 249.66 & $\mathrm{x}$ & -1.73 & 0.98 & & & $\mathrm{~g}$ \\
\hline $16 \mathrm{R}-1,8-13$ & 267.88 & $x$ & -3.70 & 0.61 & & & w \\
\hline $16 \mathrm{X}-\mathrm{CC}, 8-12$ & 267.88 & $\mathrm{x}$ & -2.29 & 1.32 & 0.707851 & 0.000008 & w \\
\hline $17 \mathrm{R}-1,22-25$ & 278.32 & $\hat{x}$ & -3.10 & 0.72 & & & w \\
\hline $19 \mathrm{R}-1,3-9$ & 297.23 & $\mathrm{x}$ & -3.72 & -0.07 & 0.707810 & 0.000013 & $\mathrm{~m}$ \\
\hline $19 \mathrm{R}-1,3-9$ & 297.23 & $x$ & -3.92 & -0.14 & & & \\
\hline $20 \mathrm{R}-1,9-13$ & 306.99 & $\hat{x}$ & -1.97 & 1.29 & & & $\mathrm{p}$ \\
\hline 20R-1, 9-13 & 306.99 & c & -2.28 & 1.65 & & & \\
\hline $20 \mathrm{R}-1,13-17$ & 307.03 & $\mathrm{x}$ & -2.90 & 0.97 & & & $w$ \\
\hline 2IR-1, $82-88$ & 317.32 & c & -1.35 & 1.55 & & & $\mathrm{p}$ \\
\hline $21 \mathrm{R}-1,110-115$ & 317.60 & $x$ & -2.31 & 1.51 & 0.707803 & 0.000007 & $\mathrm{~g}$ \\
\hline $22 \mathrm{R}-1,5-12$ & 326.25 & $x$ & -1.41 & 1.53 & & & $\mathrm{p}$ \\
\hline $22 \mathrm{R}-1,26-34$ & 326.46 & $x$ & -1.67 & 0.63 & & & w \\
\hline $22 \mathrm{R}-1,26-34$ & 326.46 & $\mathrm{x}$ & -1.64 & 0.73 & & & \\
\hline $23 \mathrm{R}-1,4-10$ & 335.84 & $\mathrm{x}$ & -2.94 & -0.68 & & & $\mathrm{~m}$ \\
\hline $23 \mathrm{R}-1.37-44$ & 336.17 & $\mathrm{x}$ & -1.56 & 1.27 & 0.707836 & 0.000009 & $\mathrm{~g}$ \\
\hline $25 \mathrm{R}-1,7-13$ & 355.17 & $\ddot{x}$ & -1.22 & 1.85 & & & $\mathrm{~g}$ \\
\hline $25 \mathrm{R}-1,7-13$ & 355.17 & c & 0.46 & 1.87 & & & \\
\hline $25 \mathrm{R}-1,18-28$ & 355.28 & $x$ & -1.19 & 1.60 & 0.707840 & 0.000009 & $\mathrm{p}$ \\
\hline $25 \mathrm{R}-1,18-28$ & 355.28 & c & 0.50 & 1.75 & & & \\
\hline $25 \mathrm{R}-1,18-28$ & 355.28 & c & -0.14 & 1.79 & & & \\
\hline $27 R-1,4-8$ & 374.34 & $x$ & -1.59 & 1.76 & & & $\mathrm{~g}$ \\
\hline $28 \mathrm{R}-1,27-30$ & 383.97 & $\mathrm{x}$ & -1.18 & 1.97 & 0.707823 & 0.000008 & $\mathrm{~g}$ \\
\hline $28 \mathrm{R}-1,66-70$ & 384.36 & $\mathrm{x}$ & -1.25 & 2.05 & & & $\mathrm{~g}$ \\
\hline $28 \mathrm{R}-1,108-111$ & 384.78 & & & & & & $\mathrm{~g}$ \\
\hline $29 \mathrm{R}-1,24-29$ & 393.64 & $\mathrm{x}$ & -1.44 & 1.93 & & & $\mathrm{~g}$ \\
\hline $30 \mathrm{R}-1,0-3$ & 403.10 & & & & & & $\mathrm{~g}$ \\
\hline $30 \mathrm{R}-1,65-68$ & 403.75 & $\mathrm{x}$ & -1.49 & 2.33 & 0.707834 & 0.000012 & $\mathrm{~g}$ \\
\hline $30 \mathrm{R}-1,113-115$ & 404.23 & $\mathrm{x}$ & -1.51 & 2.11 & & & $\mathrm{~g}$ \\
\hline $31 \mathrm{R}-1,22-25$ & 413.02 & $\mathrm{x}$ & -1.86 & 1.50 & 0.707653 & 0.000010 & $\mathrm{~g}$ \\
\hline \multicolumn{8}{|l|}{$144-874 \mathrm{~A}-$} \\
\hline $1 \mathrm{R}-1,20$ & 0.20 & $x$ & & & 0.707869 & 0.000009 & \\
\hline $1 \mathrm{R}-1,73-75$ & 0.73 & c & -0.42 & 2.62 & 0.707809 & 0.000007 & $\mathrm{~g}$ \\
\hline IR-I, 108 & 1.08 & $r$ & -4.34 & 0.92 & 0.707817 & 0.000010 & $\mathrm{r}$ \\
\hline IR-1, 108 & 1.08 & c & -0.99 & 2.61 & & & \\
\hline $1 \mathrm{R}-2,7$ & 1.57 & c & -1.53 & 2.34 & & & b \\
\hline
\end{tabular}

Mudstones and wackestones are interbedded with grain-supported limestones from $\sim 192$ to $336 \mathrm{mbsf}$, whereas grainstones dominate from $\sim 336$ to 422 mbsf.

Porosity is primarily moldic and vuggy, the latter of which results from solution enlargement of molds and interparticle voids. Interparticle porosity is only moderately prevalent, found primarily within a leached zone from 374 to 395 mbsf. Intraparticle porosity is rare because of the reduction of primary porosity by cementation; when present, however, it is commonly associated with larger benthic foraminifers. Overall, porosity varies throughout the sequence from a low of $2 \%$ to a high of $32 \%$ (Fig. 1A). Leaching of grains and interstitial material is most intense near the base of the platform, from $~ 336$ to 390 mbsf. A minor amount of pore-lining manganese oxide was observed in coral molds at a depth of $\sim 317$ mbsf.

Clear, equant, very finely to finely crystalline calcite cements are ubiquitous throughout the sequence. These cements range in size from submicroscopic to $50 \mu \mathrm{m}$ and usually occur as interparticle and

\begin{tabular}{|c|c|c|c|c|c|c|c|}
\hline $\begin{array}{l}\text { Core, section, } \\
\text { interval }(\mathrm{cm})\end{array}$ & $\begin{array}{l}\text { Depth } \\
\text { (mbsf) }\end{array}$ & ST & $\begin{array}{c}\delta^{18} \mathrm{O} \\
(\mathrm{PDB})\end{array}$ & $\begin{array}{c}\delta^{13} \mathrm{C} \\
(\mathrm{PDB})\end{array}$ & ${ }^{87} \mathrm{Sr} /{ }^{86} \mathrm{Sr}$ & $\pm 2 \sigma$ & RN \\
\hline \multicolumn{8}{|l|}{$144-874 \mathrm{~B}-$} \\
\hline $1 \mathrm{R}-1,11$ & 0.11 & $\mathrm{x}$ & & & 0.707865 & 0.000012 & \\
\hline IR-1, 22 & 0.22 & & & & & & $\mathrm{~g}$ \\
\hline IR-1, 35 & 0.35 & $\mathrm{x}$ & & & 0.707841 & 0.000011 & \\
\hline IR- $1,47-50$ & 0.47 & c & -0.2 & 2.33 & & & b \\
\hline IR-1,96 & 0.96 & & & & & & g \\
\hline $2 \mathrm{R}-1,25$ & 9.95 & c & -0.66 & 2.31 & 0.707830 & 0.000009 & w \\
\hline $2 \mathrm{R}-1,25$ & 9.95 & $\mathrm{x}$ & -0.52 & 1.79 & & & \\
\hline $2 \mathrm{R}-1,45-47$ & 10.15 & $\mathrm{x}$ & -0.52 & 1.57 & 0.707849 & 0.000009 & w \\
\hline $2 \mathrm{R}-1,45-47$ & 10.15 & $\mathrm{r}$ & -1.39 & 2.01 & & & \\
\hline $2 \mathrm{R}-1,96$ & 10.66 & $r$ & -4.12 & 1.77 & & & $\mathrm{p}$ \\
\hline $2 \mathrm{R}-2,8$ & 11.28 & & & & & & $\mathrm{p}$ \\
\hline $3 \mathrm{R}-1,43$ & 19.63 & $\mathrm{x}$ & & & 0.707850 & 0.000010 & p \\
\hline $3 R-1,63$ & 19.83 & c & -0.55 & 2.48 & & & p \\
\hline $3 R-1,138-140$ & 20.58 & $\mathrm{x}$ & -1.7 & 1.32 & 0.707860 & 0.000011 & $\mathrm{p}$ \\
\hline $3 R-2,5$ & 20.75 & $\mathrm{x}$ & & & 0.707819 & 0.000007 & \\
\hline $3 R-2,48$ & 21.18 & c & -0.73 & 1.42 & & & $\mathrm{~g}$ \\
\hline $3 R-3,38$ & 22.58 & & & & & & $\mathrm{~g}$ \\
\hline $4 \mathrm{R}-1,0-3$ & 28.70 & $\mathrm{x}$ & & & 0.707871 & 0.000014 & \\
\hline $4 R, 1-36$ & 29.06 & $\mathrm{x}$ & -1.51 & 1.78 & & & $\mathrm{p}$ \\
\hline $5 R-1,0$ & 38.10 & $r$ & $\cdot-3.66$ & 3.13 & & & $\mathrm{p}$ \\
\hline $5 \mathrm{R}-1,59$ & 38.69 & $x$ & & & 0.707871 & 0.000008 & $\mathrm{p}$ \\
\hline $5 R-1,92$ & 39.02 & & & & & & $\mathrm{p}$ \\
\hline $5 R-2,102-108$ & 40.62 & $r$ & -4.11 & 1.59 & 0.707850 & 0.000009 & $\mathrm{p}$ \\
\hline $5 R-2,102-108$ & 40.62 & $\mathrm{pn}$ & -3.40 & 2.20 & & & \\
\hline $6 \mathrm{R}-1,64$ & 48.24 & $x$ & & & 0.707803 & 0.000009 & $\mathrm{p}$ \\
\hline $6 \mathrm{R}-1,114-117$ & 48.74 & $\mathrm{x}$ & -1.68 & 1.73 & 0.707840 & 0.000014 & $r$ \\
\hline $6 \mathrm{R}-1,114-117$ & 48.74 & c & -1.02 & 1.92 & & & b \\
\hline $6 \mathrm{R}-1,143$ & 49.03 & $\mathrm{x}$ & & & 0.707845 & 0.000015 & b \\
\hline $6 R-2,8$ & 49.18 & $\mathrm{x}$ & & & 0.707814 & 0.000011 & $\mathrm{~g}$ \\
\hline $7 \mathrm{R}-1,10$ & 57.30 & $\mathbf{r}$ & -3.07 & 1.51 & & & $\mathrm{r}$ \\
\hline $8 \mathrm{R}-1,4$ & 66.94 & $\mathrm{x}$ & -1.58 & 1.01 & 0.707834 & 0.000009 & $\mathrm{p}$ \\
\hline $8 \mathrm{R}-1,46$ & 67.36 & $\mathrm{x}$ & & & 0.707801 & 0.000008 & \\
\hline $9 \mathrm{R}-1,26$ & 76.86 & $\mathrm{x}$ & & & 0.707810 & 0.000010 & b \\
\hline $9 \mathrm{R}-1,70$ & 77.30 & $x$ & & & 0.707852 & 0.000011 & \\
\hline $9 \mathrm{R}-1,107$ & 77.67 & & & & & & $\mathrm{p}$ \\
\hline $9 \mathrm{R}-1,129-131$ & 77.89 & $\mathrm{x}$ & & & 0.707839 & 0.000010 & \\
\hline $9 R-2,5$ & 78.15 & $x$ & & & 0.707829 & 0.000010 & $\mathrm{p}$ \\
\hline $10 \mathrm{R}-1,0$ & 86.20 & $\mathrm{x}$ & -0.62 & 1.98 & 0.707800 & 0.000009 & $\mathrm{p}$ \\
\hline $11 \mathrm{R}-1,7$ & 91.27 & $r$ & -0.58 & 1.7 & 0.707851 & 0.000012 & $\mathrm{p}$ \\
\hline $12 \mathrm{R}-1,0$ & 96.20 & $\mathrm{x}$ & & & 0.707820 & 0.000011 & $\mathrm{p}$ \\
\hline $16 \mathrm{R}-1,4$ & I1 16.84 & $\mathrm{x}$ & & & 0.707806 & 0.000009 & \\
\hline $16 \mathrm{R}-1,40$ & 117.20 & $\mathrm{x}$ & & & 0.707810 & 0.000008 & $\mathrm{~g}$ \\
\hline $17 \mathrm{R}-1,13-15$ & 126.53 & $\mathrm{x}$ & & & 0.707876 & 0.000014 & \\
\hline $17 \mathrm{R}-1,63$ & 127.03 & & & & & & g \\
\hline $18 \mathrm{R}-1,26$ & 136.26 & $\mathrm{x}$ & & & 0.707834 & 0.000007 & \\
\hline $18 R-1,66$ & 136.66 & $\mathrm{x}$ & & & 0.707830 & $\begin{array}{l}0.000009 \\
0.000012\end{array}$ & $\mathrm{~g}$ \\
\hline $19 \mathrm{R}-1,16$ & 143.66 & $x$ & -1.97 & 2.54 & 0.707730 & & $\mathrm{~g}$ \\
\hline $\begin{array}{l}19 \mathrm{R}-1,53-55 \\
19 \mathrm{R}-1,67\end{array}$ & $\begin{array}{l}144.03 \\
144.17\end{array}$ & $\begin{array}{l}\mathrm{c} \\
\mathrm{x}\end{array}$ & -1.91 & & 0.707745 & 0.000010 & b \\
\hline $19 \mathrm{R}-1,93$ & 144.43 & c & -1.63 & 2.55 & & & $\mathrm{~g}$ \\
\hline $19 \mathrm{R}-1,132$ & 144.82 & $\mathrm{x}$ & & & 0.707749 & 0.000013 & \\
\hline $19 \mathrm{R}-1,145$ & 144.95 & & & & & & $\mathrm{~g}$ \\
\hline $20 \mathrm{R}-1,5-7$ & 153.15 & $\mathrm{x}$ & & & 0.707772 & 0.000010 & g \\
\hline $20 \mathrm{R}-1,18$ & 153.28 & $\mathrm{x}$ & & & 0.707749 & 0.000009 & \\
\hline
\end{tabular}

Notes: $\mathrm{ST}=$ sample type, $\mathrm{RN}=$ rock name, $\mathrm{x}=$ matrix and $\mathrm{c}=$ cement, including $\mathrm{g}=$ grainstone, $\mathrm{p}=$ packstone, $\mathrm{w}=$ wackstone, and $\mathrm{m}=$ mudstone.

intraparticle, pore-filling mosaics. Finely crystalline cements less commonly line and fill molds and vugs. Localized, equant to bladed cements $(70-200 \mu \mathrm{m})$ are moderately prevalent, especially between $\sim 307$ and 422 mbsf. These subhedral to euhedral crystals occur as slightly drusy mosaics within molds, and they also fill interparticle porosity in samples near the base of the platform. Syntaxial calcite overgrowths and isopachous, finely crystalline, bladed cements are much less common throughout the sequence. Bladed, grain-lining cements consist of crystals $10-40 \mu \mathrm{m}$ in length and $<5-10 \mu \mathrm{m}$ in width, which are succeeded by equant spars toward their pore centers.

Cements generally comprise $\sim 5 \%-20 \%$ of the limestone samples, with a few grainstones consisting of $>25 \%$ cement (Fig. 1B). There is no obvious correlation between porosity and cement abundances ( $\mathrm{R}=0.13$ ). Although the majority of Hole $871 \mathrm{C}$ limestones are noncathodoluminescent, a few thin sections display small zones of dull luminescence, and a single sample from the base of the platform ( $\sim 13 \mathrm{mbsf}$ ) displays an overall bright luminescence. 


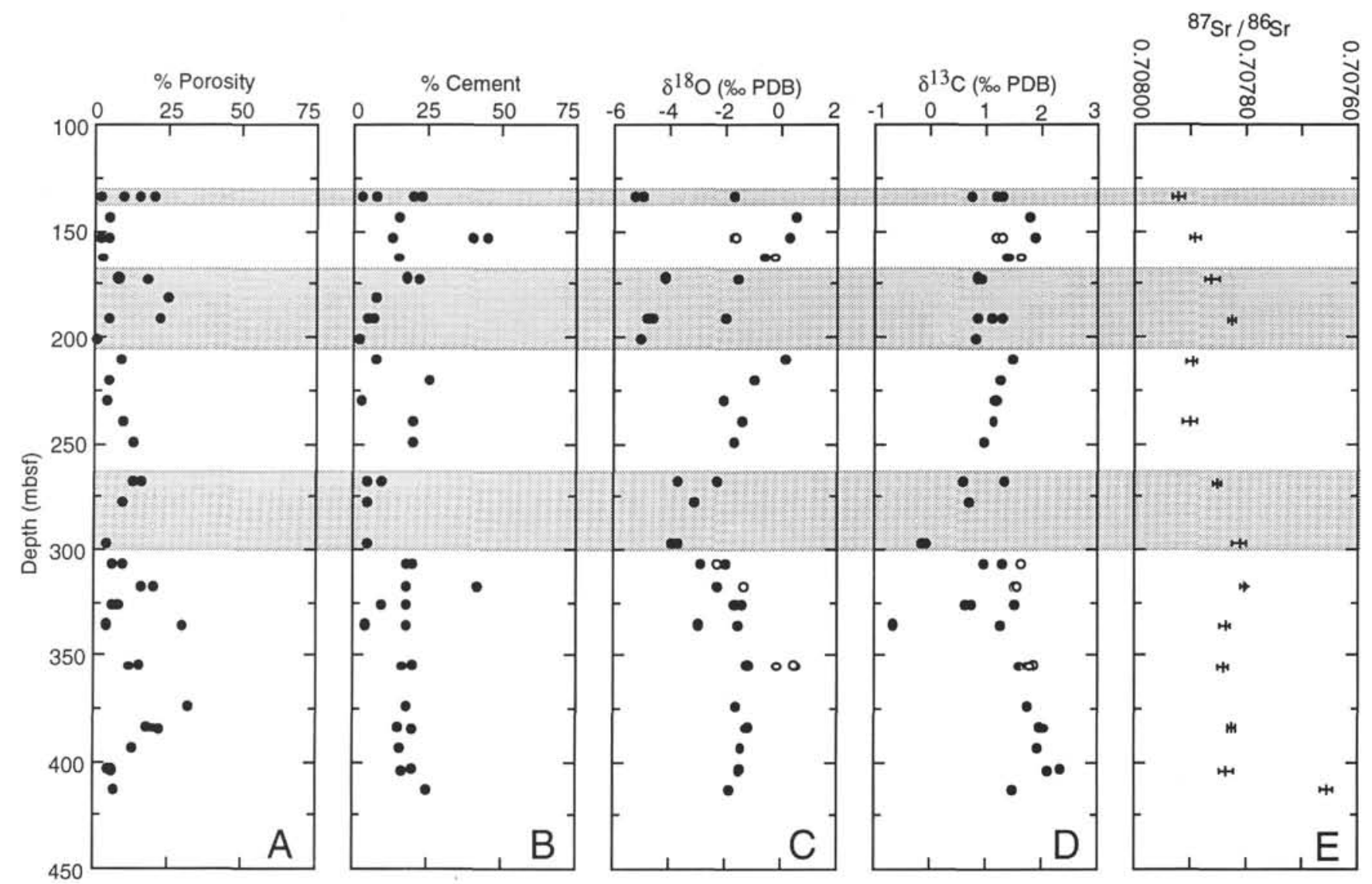

Figure 1. Variations in textural characteristics and isotope values with depth in carbonates from Hole 871C. A. Porosity vs. depth (mbsf). Porous intervals at $\sim 134$ mbsf and between $\sim 172$ and $200 \mathrm{mbsf}$ coincide with intervals of low $\delta^{18} \mathrm{O}$. B. Cementation vs. depth. C. $\delta^{18} \mathrm{O}$ vs. depth. Intervals with $\delta^{18} \mathrm{O}$ values $\leq-0.3 \%$ are interpreted to have undergone alteration in the meteoric environment. D. $\delta^{13} \mathrm{C}$ vs. depth. $\delta^{13} \mathrm{C}$ is fairly constant throughout the sequence (average $\sim 1.0 \%$ to $1.5 \%$ ), but increases with increasing depth at $\sim 350 \mathrm{mbsf} . \mathbf{E} .{ }^{87} \mathrm{Sr} /{ }^{86} \mathrm{Sr}$ vs. depth. These data are consistent with an early Paleogene age; however, the temporal resolution of seawater $\mathrm{Sr}$ isotopes is minimal during this time. In Figures $1 \mathrm{C}$ and $\mathrm{ID}$, closed circles denote matrix samples and open circles denote cement samples. Stippled areas indicate zones that have interacted with meteoric waters.

Oxygen and carbon stable-isotope ratios were determined for 40 matrix and 8 cement samples (Table 1$). \delta^{18} \mathrm{O}$ values vary over a wide range (from $-5.28 \%$ to $0.50 \%$ ), whereas $\delta^{13} \mathrm{C}$ values are high and relatively invariant (from $-0.68 \%$ to $2.33 \%$; Fig. 2). For 23 matrix samples and half of the cement samples, $\delta^{18} \mathrm{O}$ and $\delta^{13} \mathrm{C}$ values range from $-2.31 \%$ to $-0.95 \%$ and from $0.63 \%$ to $2.33 \%$, respectively. Four cement samples and 4 matrix samples have higher $\delta^{18} \mathrm{O}$ values (between $-0.61 \%$ and $0.50 \%$ o). The remaining 13 matrix samples have noticeably lower $\delta^{18} \mathrm{O}$ values, ranging from $-5.28 \%$ to $-2.9 \%$; 3 of these have $\delta^{13} \mathrm{C}$ values between $-0.68 \%$ and $-0.07 \%$. Samples with depleted oxygen isotope values are concentrated in three zones: $\sim 134$ mbsf, from $\sim 172$ to $209 \mathrm{mbsf}$, and from $\sim 266$ to 305 mbsf (Fig. 2C).

${ }^{87} \mathrm{Sr} /{ }^{86} \mathrm{Sr}$ values vs. depth (mbsf) for 14 samples are plotted in Figure 1E. Four samples recovered from $\sim 134$ to 192 mbsf show a trend of steadily decreasing ${ }^{87} \mathrm{Sr} /{ }^{86} \mathrm{Sr}$ values with increasing depth, from $0.707916 \pm 0.000011$ to $0.707824 \pm 0.000007$. From $\sim 211$ to $240 \mathrm{mbsf},{ }^{87} \mathrm{Sr} /{ }^{86} \mathrm{Sr}$ becomes more constant, at $\sim 0.70789 .{ }^{87} \mathrm{Sr} /{ }^{86} \mathrm{Sr}$ again decreases from 240 to 297 mbsf and then remains fairly constant for $\sim 100 \mathrm{~m}$. One sample recovered from the base of the platform $(\sim 413 \mathrm{mbsf})$ has a ${ }^{87} \mathrm{Sr} /{ }^{86} \mathrm{Sr}$ value of $0.707653 \pm 0.000010$, distinctly lower than all other samples.

\section{Wodejebato (Site 874)}

The neritic carbonate interval in Hole $874 \mathrm{~B}$ extends from 0.11 to $162.82 \mathrm{mbsf}$, and is overlain by a $10-\mathrm{cm}$-thick iron-manganese and phosphatic crust. The upper $\sim 10 \mathrm{~m}$ of the platform consists of interbed- ded, foraminifer-rudist grainstones, rudstones, coral boundstones, and minor wackestones (Table 1). Limestones from 10 to $117 \mathrm{mbsf}$ are dominantly poorly sorted, foraminifer-rudist packstones, interbedded occasionally with minor zones of grainstones, rudstones, and boundstones. The lowermost interval from $\sim 117$ to 162 mbsf consists of well-sorted grainstones.

Fabric selective, moldic porosity is ubiquitous throughout the hole, whereas vuggy, solution-enlarged moldic and interparticle porosity is also common (Fig. 3C). These molds have most commonly formed from the dissolution of mollusks, especially rudist bivalves. Porosity within the top $\sim 38 \mathrm{~m}$ of limestones has been moderately reduced by cementation, whereas molds in the lower $\sim 124 \mathrm{~m}$ are largely free of cements. The dissolution of skeletal grains is most intense between $\sim 67$ and 145 mbsf. Porosity in Hole $874 \mathrm{~B}$ is typically between $\sim 10 \%$ and $20 \%$, but it is less than $35 \%$ in a few samples (Fig. 4A).

Calcite cements display diverse morphologies and sizes, and most are cloudy and inclusion rich. Although cements commonly occur as grain-replacing and mold-filling mosaics, they are also found in interparticle spaces. Prismatic, isopachous spar $(60 \mu \mathrm{m}$ to $1 \mathrm{~mm})$ with undulose extinction is found in almost all samples, usually replacing bivalve fragments (Fig. 3A). Although this neomorphic cement is typically cloudy, the internal microstructure of many bivalve grains remains discernible. Coarse-crystalline syntaxial overgrowths are also a common cement type in Hole 874B samples. Crusts of isopachous, medium-crystalline, radiaxial-bladed cement line large voids in the upper few meters of the platform (Fig. 3B). These cements are cloudy and light brown in color from the abundant inclusions; they are 
typically $\sim 100 \mathrm{~mm}$ in length and $\sim 30 \mu \mathrm{m}$ in width. Another form of bladed cement is clear, isopachous spar $(30 \mu \mathrm{m})$, which lines molds and/or interparticle voids in several samples (Fig. 3C). In some cases, these first-generation, interparticle crystals are succeeded by coarser, equant to bladed cements toward their pore centers. Equant and nonisopachous bladed cements vary from very finely to coarsely crystalline and occur as interparticle and moldic, pore-filling mosaics. Although cements commonly comprise $\sim 15 \%-20 \%$ of the samples, they comprise $\sim 25 \%-35 \%$ in the limestone samples at depths less than 10 mbsf and from $\sim 117$ to 145 mbsf.

A few samples consist of chalky limestone, in which all grains (including benthic foraminifers) have undergone dissolution and replacement by cements. In addition, micritized grains and micrite rims around molds are quite abundant throughout the sequence. Very minor concentrations of heavy minerals occur at the top and near the base of Hole 874B. Brown-stained phosphate grains are mixed with pelagic foraminifers in Sample 144-874B-1R-1, 47-50 cm, whereas Samples 144-874B-16R-1, 40-42 cm, and -17R-1, 63-65 cm ( 117$127 \mathrm{mbsf}$ ), contain a few red- and dark brown-stained grains.

Cathodoluminescence is negligible in upper-platform samples $(0$ $50 \mathrm{mbsf}$ ). Luminescence increases from non- to dull-bright from 50 to $77 \mathrm{mbsf}$, decreases to non-dull at a depth of $96 \mathrm{mbsf}$, and then increases again from non-dull to bright from 116 to $163 \mathrm{mbsf}$ (no core recovery from $\sim 102$ to $116 \mathrm{mbsf}$ ). Cathodoluminescence is brightest at the base of the sequence and is particularly intense in a few grains that are reddish brown in plane light ( 117-127 mbsf).

Oxygen and carbon stable-isotope ratios were determined for 7 matrix samples, 10 cement samples, 7 rudist samples, and 1 prismatonacreous bivalve sample from Holes 874A and 874B (Table 1). The bivalves that were sampled for isotopic analyses have been replaced by prismatic cements and display very little original microstructure. All samples from both holes have high $\delta^{13} \mathrm{C}$ values that fall between $0.92 \%$ and $3.13 \%$ (Fig. 5). All matrix samples, 2 rudists, and the majority of the void-filling cements have $\delta^{18} \mathrm{O}$ values that cluster between $-1.97 \%$ and $-0.20 \%$. The remaining 8 bivalve samples have lower $\delta^{18} \mathrm{O}$ values, ranging from $-4.34 \%$ to $-3.07 \%$. Samples with low oxygen-isotope values are primarily concentrated at $\sim 40 \mathrm{mbsf}$, but they can also be found in the upper $10 \mathrm{~m}$ of the platform (Fig. 4C).

$\mathrm{Sr}$-isotope analyses of 36 samples indicate that the ${ }^{87} \mathrm{Sr} /{ }^{86} \mathrm{Sr}$ ratio varies from $0.707869 \pm 0.000009$ near the top of the sequence to $0.707730 \pm 0.000012$ near the base of the sequence (Fig. 4E). ${ }^{87} \mathrm{Sr} /{ }^{86} \mathrm{Sr}$ values are fairly constant to a depth of $\sim 140 \mathrm{mbsf}$, averaging from $\sim 0.70780$ to 0.70786 . A slight offset from this trend occurs at $\sim 144$ mbsf, where Sr-isotope values decrease to $0.707730 \pm 0.000012$ (Sample 144-874B-19R-1, 16-18 cm).

\section{DISCUSSION}

\section{Limalok (Site 871)}

Enriched $\delta^{18} \mathrm{O}$ and $\delta^{13} \mathrm{C}$ values in diagenetic carbonates are consistent with marine alteration, whereas depleted, stratigraphically homogenous $\delta^{18} \mathrm{O}$ values and variable $\delta^{13} \mathrm{C}$ values are more consistent with alteration in the meteoric environment (e.g., Allan and Matthews, 1982; Lohmann, 1988). The majority of samples from Hole 871C have high stable-isotope values (i.e., $\delta^{18} \mathrm{O}>-3.0 \%, \delta^{13} \mathrm{C}>0.5 \%$ ) and invariant $\delta^{13} \mathrm{C}$ values (Fig. 2), which are consistent with diagenetic alteration in the marine environment. However, there are three zones (Fig. 1C) in which $\delta^{18} \mathrm{O}$ values are noticeably lower and thus seem to reflect interaction with an isotopically depleted fluid, which is most likely meteoric water. These isotopic data, combined with petrographic observations outlined below, indicate a multiphase, multifluid diagenetic history for Limalok Guyot platform carbonates.

Early marine diagenetic modification of Hole $871 \mathrm{C}$ carbonates included the reduction of inter- and intraparticle porosity through the precipitation of equant to slightly bladed cements $(10-50 \mu \mathrm{m})$. Fringing, isopachous, fibrous cements that commonly occur in modern shallow-marine settings (e.g., James and Choquette, 1990b) are rare

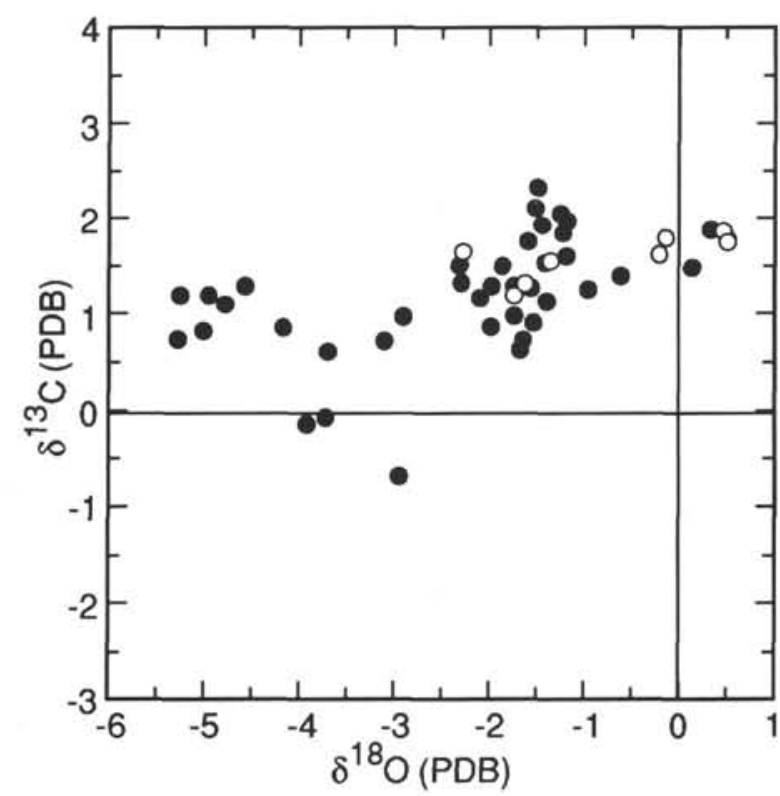

Figure 2. Cross-plot of $\delta^{13} \mathrm{C}$ and $\delta^{18} \mathrm{O}$ values of matrix (closed circles) and cement (open circles) samples from Hole 871C. All cement samples and several matrix samples have high $\delta^{13} \mathrm{C}$ and $\delta^{18} \mathrm{O}$ values, an isotopic relation consistent with diagenetic alteration in the marine environment. Several matrix samples have low $\delta^{18} \mathrm{O}$ values $(-5.28 \%$ to $-3.92 \%)$ and moderate $\delta^{13} \mathrm{C}$ values $(-0.68 \%$ to $1.29 \%)$. Samples with low $\delta^{18} \mathrm{O}$ values, especially those that cluster around $-5 \%$, are interpreted to have undergone diagenetic alteration in the meteoric environment.

in these samples, occurring only in the lowermost portion of the sequence ( $385 \mathrm{mbsf})$. Coarsely crystalline, interparticle, and moldfilling mosaic cements with equant to bladed morphologies are found throughout the sequence. In previous studies, this type of cement was interpreted to have originated in a meteoric phreatic environment (e.g., James and Choquette, 1990a). However, these cements are generally absent from zones of low $\delta^{18} \mathrm{O}$ in Hole $871 \mathrm{C}$. In fact, all cements that were sampled for isotopic analysis have $\delta^{18} \mathrm{O}$ values (from $-2.28 \%$ to $0.50 \%$ ) that are consistent with precipitation in the marine environment.

High $\delta^{18} \mathrm{O}$ values in samples with well-developed moldic porosity and/or equant cements may have resulted from deep-marine diagenesis. The precipitation of equant cements in deep-sea carbonates was reported by Freeman-Lynde et al. (1986). Such cements should have relatively high $\delta^{18} \mathrm{O}$ values because of precipitation in deep, cold marine waters. We note that many of our equant cement samples have high $\delta^{18} \mathrm{O}$ values (from $-0.5 \%$ to $0.5 \%$ ); hence, we interpret these as deep marine in origin.

Diagnostic features of subaerial exposure, such as meniscus cements (Dunham, 1971), oxidized crusts, and root structures (e.g., James and Choquette, 1990a) were not observed in Hole 871C samples. Although cathodoluminescence in carbonates is commonly associated with meteoric diagenesis (e.g., Wagner and Matthews, 1982; Ward et al., 1985), virtually all samples are nonluminescent. The most significant petrographic evidence for meteoric alteration within these carbonates is the presence of well-developed moldic to vuggy porosity. Intervals of low $\delta^{18} \mathrm{O}$ values (matrix samples) are characterized by moderate to extensive dissolution, especially from $\sim 172$ to 192 mbsf (Fig. 1A). In most cases, these pores have not been significantly reduced by cements. An increase in porosity and cementation, as well as a minor manganese hydroxide buildup within a coral mold (Sample 144-871C-21R, 110-115 cm), occurs at a possible unconformity $(\sim 317$ mbsf) reported by the Shipboard Scientific Party (1993). Finally, Samples 144-871C-2R-1, 27-32 cm; -16R-1, 8-13 cm; and -17R-1, 22-25 

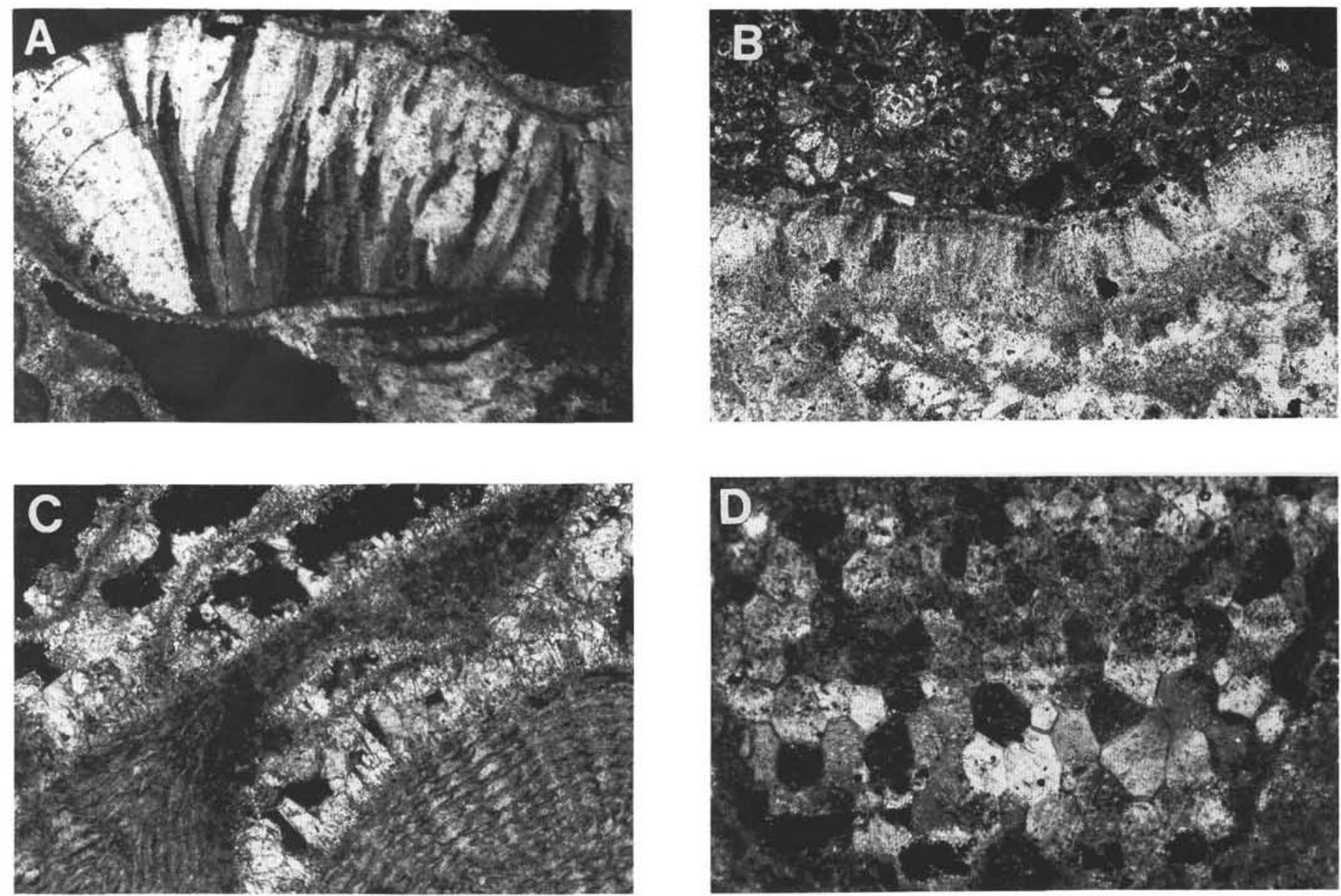

Figure 3. Thin-section photomicrographs showing diagenetic textures of shallow-water limestones from Wodejebato Guyot, Hole 874B. A. Large rudist fragment replaced by prismatic cement. B. Contact between cloudy, isopachous, bladed marine cements and overlying pelagic sediments. C. Micrite-rimmed molds with pore-lining, thin-bladed cements. Large benthic foraminifers in bottom half of photo. D. Top view of polygonal calcite prisms of a prismato-nacreous bivalve. Field of view is $5 \mathrm{~mm}$ (Figs. 3A-3B) and $2 \mathrm{~mm}$ (Figs. 3C-3D).

$\mathrm{cm}$, are chalky because of their extensive alteration, and these samples have depleted $\delta^{18} \mathrm{O}$ values (from approximately $-5 \%$ to $-3 \%$ ).

Offsets in strontium-isotope stratigraphy have previously been used to recognize subaerial exposure surfaces (e.g., Ludwig et al., 1988). Although ${ }^{87} \mathrm{Sr} /{ }^{86} \mathrm{Sr}$ values in Hole $871 \mathrm{C}$ samples are fairly constant throughout the sequence, a slight offset in ${ }^{87} \mathrm{Sr} /{ }^{86} \mathrm{Sr}$ values occurs at the base of the platform ( 410 mbsf), between Samples 144-871C-30R-1, 65-68 cm, and -31R-1, 22-25 cm (Fig. 1E). This offset, which is nine times greater than the analytical error, correlates with a dramatic increase in cathodoluminescence and may be the result of a period of subaerial exposure, or perhaps the result of interaction with the underlying volcanic substrate. More data are needed to determine the cause of this offset. Overall, the Sr-isotope data are consistent with an early Paleogene age; however, they provide few additional age constraints as the temporal resolution of seawater $\mathrm{Sr}$-isotope stratigraphy is minimal during this time.

\section{Wodejebato (Site 874)}

A cross-plot of oxygen and carbon isotope values for samples from Holes $874 \mathrm{~A}$ and $874 \mathrm{~B}$ (Fig. 5) shows a distribution similar to that for limestones from Hole $871 \mathrm{C}$. The majority of samples from Hole $874 \mathrm{~B}$ have high $\delta^{18} \mathrm{O}$ and $\delta^{13} \mathrm{C}$ values (i.e., $\delta^{18} \mathrm{O}>-2.0 \%$ and $\delta^{13} \mathrm{C}>1.0 \%$ ) and invariant $\delta^{13} \mathrm{C}$ values. Almost all inclusion-rich, radiaxial-bladed cements that were sampled for isotopic analysis have high $\delta^{18} \mathrm{O}$ values $(\sim-1 \%$ to $-0.2 \%$ ) that are consistent with precipitation in cold, deep seawater. These precipitates are very similar in appearance to cements in Anewetak (formerly Enewetak) Atoll carbonates, which were also interpreted to be deep marine in origin (Saller, 1986).

Based on petrographic observations, only two cement samples that were drilled for isotopic analysis (Samples 144-874B-19R-1, $53-55 \mathrm{~cm}$, and $-19 \mathrm{R}-1,93-95 \mathrm{~cm}$ ) appear to have precipitated in the marine environment. We think that these interparticle, fibrous to bladed cements have $\delta^{18} \mathrm{O}$ and $\delta^{13} \mathrm{C}$ values $(-1.97 \%$ and $2.54 \%$; $-1.63 \%$ and $2.55 \%$, respectively) that most closely reflect a Maastrichtian seawater isotopic composition, as these values are similar to Tethyan seawater $\delta^{18} \mathrm{O}$ and $\delta^{13} \mathrm{C}$ values (average $-2.2 \%$ and $3.55 \%$, respectively) previously reported from aragonitic, Upper Cretaceous rudists from the Coon Creek Tongue-Ripley Formation of Tennessee (Al-Aasm and Veizer, 1986). All of our cement isotopic data also fall within the range of isotopic values of Cretaceous deep-marine cements from the Bahama Escarpment, in which $\delta^{18} \mathrm{O}$ values range from $-3.1 \%$ to $0.1 \%$ and $\delta^{13} \mathrm{C}$ values range from $0.6 \%$ to $3.4 \%$ (FreemanLynde et al., 1986).

The petrography of carbonates from Holes $874 \mathrm{~A}$ and $874 \mathrm{~B}$ indicate that these rocks have undergone multiple episodes of diagenetic alteration. Micritization occurred initially, as evidenced by micrite rims around molds. The entire sequence is well cemented, but it is difficult to determine a unique environment of precipitation for these cements. Widespread dissolution of metastable grains occurred throughout the sequence, and many of the resulting molds were later filled by fibrous and equant to bladed spar. A large number of rudist bivalves have been neomorphically replaced by prismatic cements and can be identified by their well-preserved microstructure. 


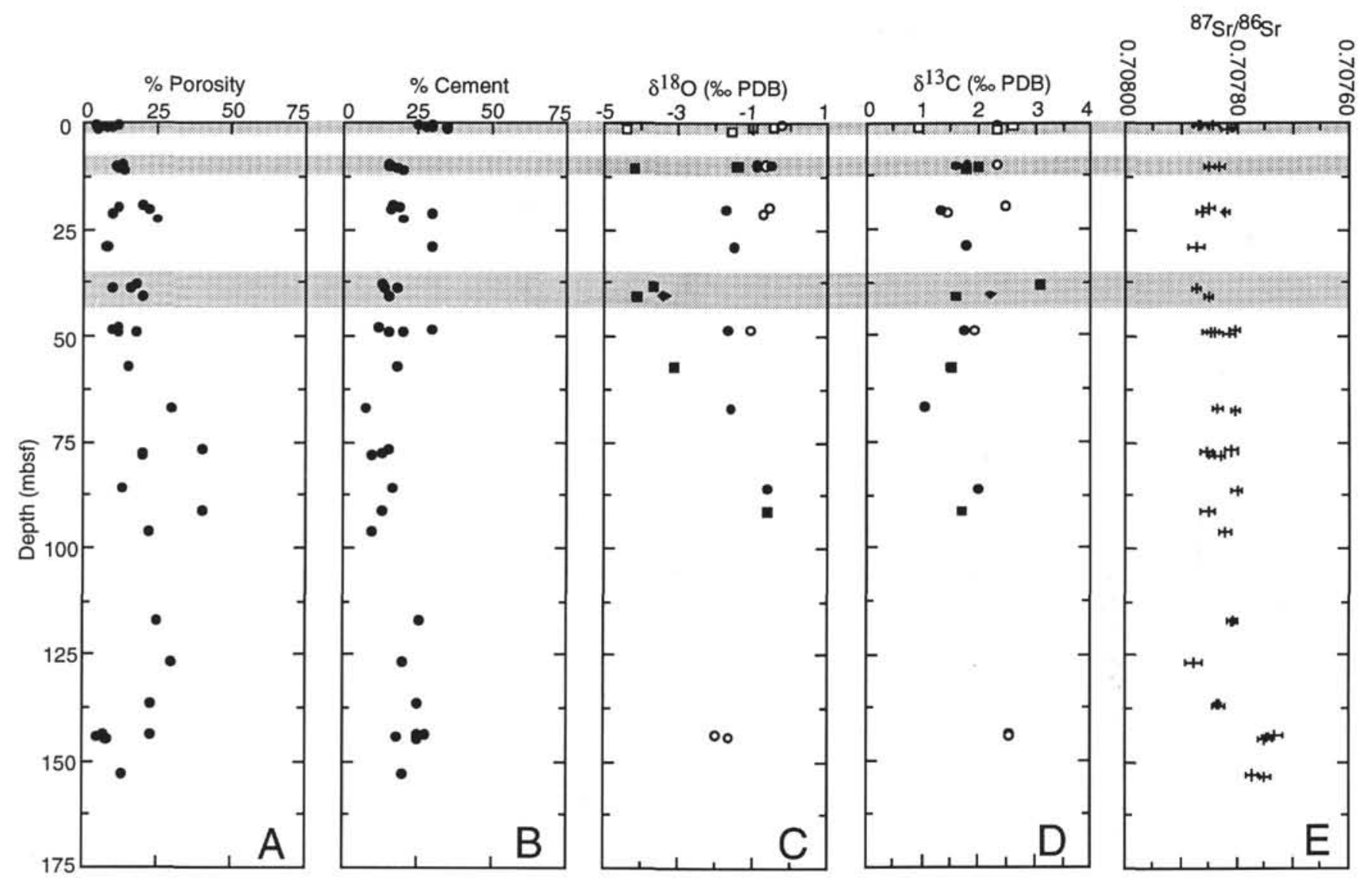

Figure 4. Variation in textural characteristics and isotope values with depth in carbonates from Holes 874A and 874B. A. Porosity vs. depth (mbsf). B. Cementation vs. depth. C. $\delta^{18} \mathrm{O}$ vs. depth. D. $\delta^{13} \mathrm{C}$ vs. depth. $\delta^{13} \mathrm{C}$ ranges from $0.92 \%$ to $3.13 \%$. E. ${ }^{87} \mathrm{Sr} /{ }^{86} \mathrm{Sr}$ vs. depth. Values are fairly constant with depth, with a slight decrease in ${ }^{87} \mathrm{Sr} /{ }^{86} \mathrm{Sr}$ at $\sim 144 \mathrm{mbsf}$. In Figures $4 \mathrm{C}$ and $4 \mathrm{D}$, cement samples from Hole $874 \mathrm{~A}$ are denoted by open squares, and matrix, cement, rudist, and prismato-nacreous bivalve samples from Hole 874B are denoted with closed circles, open circles, closed squares, and closed diamonds, respectively. Stippled areas indicate zones that have interacted with meteoric waters at low water/rock ratios.

Five neomorphosed rudist samples and one neomorphosed prismato-nacreous bivalve (Fig. 3D) from Holes 874A and 874B have low $\delta^{18} \mathrm{O}$ values (from $-4.34 \%$ to $-3.07 \%$ ) and relatively high $\delta^{13} \mathrm{C}$ values (from $0.92 \%$ to $3.13 \%$ ). Petrographically, these skeletal grains have been replaced by prismatic spar, yet have retained very minor, relict microstructures of the original bioclast. The isotopic values of these neomorphic products are most consistent with precipitation from a meteoric fluid, as carbonate precipitation from normal salinity seawater should produce high $\delta^{18} \mathrm{O}$ and $\delta^{13} \mathrm{C}$ values, the former of which we do not observe in these samples. We envision two similar scenarios that can explain the coincidence of low $\delta^{18} \mathrm{O}$ and high $\delta^{13} \mathrm{C}$ values in these samples. First, neomorphic alteration of marine carbonates in meteoric fluids at low water/rock ratios could have lowered the $\delta^{18} \mathrm{O}$ values of these samples while leaving the $\delta^{13} \mathrm{C}$ values virtually unchanged (i.e., alteration along the horizontal limb of the J-shaped curve of Lohmann, 1988). Second, neomorphic alteration of carbonates with low $\delta^{18} \mathrm{O}$ and high $\delta^{13} \mathrm{C}$ values in meteoric fluids at very low water/rock ratios (i.e., an essentially closed-system, rockdominated environment) could have produced the observed isotopic values. Low $\delta^{18} \mathrm{O}$ values in many modern marine carbonates are explained by kinetic and/or "vital" effects (e.g., McConnaughey, 1989); however, high $\delta^{13} \mathrm{C}$ values are not commonly associated with disequilibrium precipitation. We favor the first scenario because it is the most straightforward and least speculative.

Cathodoluminescent intervals in Hole 874B carbonates do not coincide with zones of low $\delta^{18} \mathrm{O}$ values. Luminescence increases (from 50 to $77 \mathrm{mbsf}$ ) from non- to dull-bright just beneath a zone of meteoric alteration (at $\sim 40$ mbsf); however, most carbonates within this moderately bright interval have rather high $\delta^{18} \mathrm{O}$ values (from approximately $-1.0 \%$ to $-1.7 \%$ ). Cathodoluminescence is brightest near the base of the platform (from approximately 116 to $163 \mathrm{mbsf}$ ), but we only have two stable-isotope values in this interval, which we interpret as marine in origin (Figs. 4C-4D).

${ }^{87} \mathrm{Sr} /{ }^{86} \mathrm{Sr}$ values for samples from Site 874 are fairly constant throughout the sequence, with a few samples possessing slightly lower values at $>144 \mathrm{mbsf}$ (Fig. $4 \mathrm{E}$ ) ${ }^{87} \mathrm{Sr} /{ }^{86} \mathrm{Sr}$ values at the top of the platform $(\sim 0.707869)$ are consistent with a Maastrichtian age ( 67 $\mathrm{Ma})$, whereas ${ }^{87} \mathrm{Sr} /{ }^{86} \mathrm{Sr}$ values near the base $(\sim 0.707730)$ are consistent with a latest Campanian age ( $72 \mathrm{Ma})$. Based upon these data and correlation to the global seawater Sr-isotope curve for the Late Cretaceous of McArthur et al. (1994), the Campanian/Maastrichtian boundary is most likely between 136.66 and $143.66 \mathrm{mbsf}$. As no clear Sr-isotope offsets were observed, these data do not provide evidence for subaerial exposure of the carbonate platform at Wodejebato Guyot.

\section{CONCLUSIONS}

Petrographic and geochemical data from Limalok (Hole 871C) and Wodejebato (Holes 874A and 874B) indicate that these guyots have had a relatively similar diagenetic history, and allow us to make the following conclusions.

Most of the stable-isotope data are consistent with alteration in a marine setting. However, low $\delta^{18} \mathrm{O}$ values in samples from Holes 


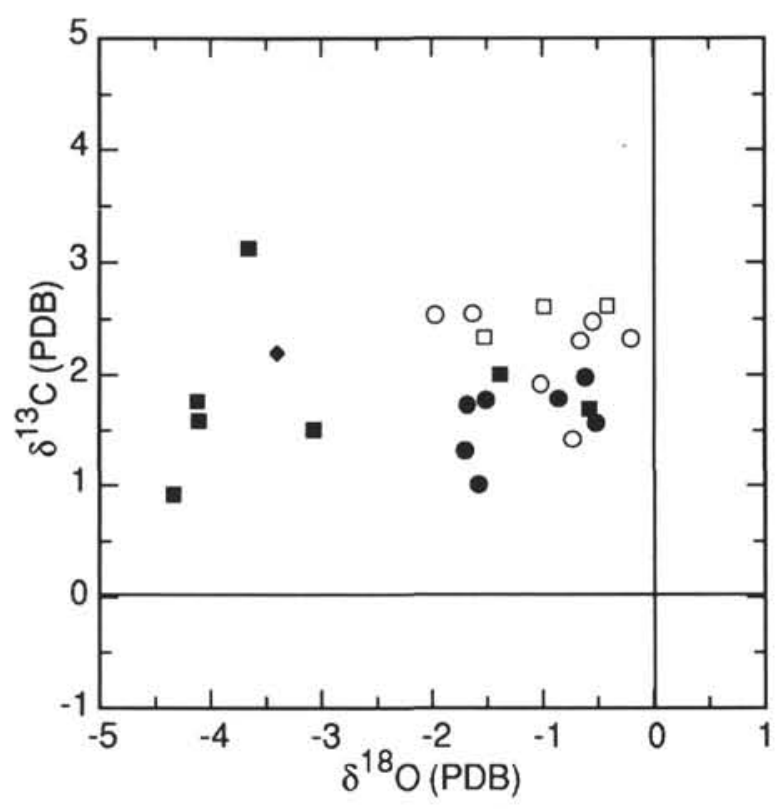

Figure 5. Cross-plot of $\delta^{13} \mathrm{C}$ and $\delta^{18} \mathrm{O}$ values of samples from Holes $874 \mathrm{~A}$ and 874B. Cement samples from Hole 874A are denoted by open squares. Matrix, cement, rudist, and prismato-nacreous bivalve samples from Hole 874B are denoted with closed circles, open circles, closed squares, and closed diamonds, respectively. All samples have high $\delta^{13} \mathrm{C}$ values, ranging from $0.92 \%$ to $3.13 \%$. $\delta^{18} \mathrm{O}$ values cluster in two groups: the higher values range from $-1.97 \%$ to $-0.20 \%$, and the lower values range from $-4.34 \%$ to $-3.07 \%$. The former group is interpreted to have undergone marine alteration, and the latter group is interpreted to have undergone alteration by meteoric water at low water/rock ratios.

$871 \mathrm{C}, 874 \mathrm{~A}$, and $874 \mathrm{~B}$ are consistent with alteration in the meteoric environment at low water/rock ratios.

Intervals with stable-isotope values consistent with meteoric diagenesis are generally characterized by the increased dissolution of allochems.

In general, petrographic observations suggest the following sequence of diagenetic modification for both platforms: micritization of allochems; precipitation of finely crystalline, equant, and slightly bladed cements; widespread dissolution of metastable allochems; precipitation of mold-filling, mosaic, equant to bladed cements; and localized fringing isopachous cements. Although the equant, mosaic cements and associated moldic/vuggy porosity are often considered indicative of meteoric diagenesis, high $\delta^{18} \mathrm{O}$ values in fact support a marine origin.

$\mathrm{Sr}$ isotopes provide few age constraints on carbonates from Hole $871 \mathrm{C}$ because of the poor resolution of seawater $\mathrm{Sr}$-isotope trends in the early Paleogene. Sr-isotope data on carbonates from Holes 874A and $874 \mathrm{~B}$ indicate that these sediments were deposited beginning in the latest Campanian and ending in the Maastrichtian. We place the Campanian/Maastrichtian boundary, defined by U.S. Western Interior and Northwest European macrofossils, between 136.66 and 143.66 mbsf in Hole 874B.

Although zones occur in both sequences that we interpret to have undergone alteration in the meteoric environment, we found no direct evidence of any subaerial exposure surfaces. Finally, the homogenous ${ }^{87} \mathrm{Sr} /{ }^{86} \mathrm{Sr}$ data do not show any sedimentary gap that would be associated with subaerial exposure.

\section{ACKNOWLEDGMENTS}

This paper represents a portion of the first author's Master's thesis, completed under the direction of Terrence M. Quinn at the University of South Florida. This work was supported by a grant from
JOI/USSAC. The authors wish to thank Leanne Roulier, Suzanne Link, Joe Alex, Stephen Schellenberg, and Keith Marshall for invaluable assistance during this project; Coos van Belle and Franz Benavente of the radiogenic chemistry lab at Vrije Universiteit for their technical assistance; ODP reviewers R.P. Major, C.E. Jones, and J. Marin for their thoughtful suggestions; and the Leg 144 Shipboard Scientific Party for their assistance during the cruise.

\section{REFERENCES}

Aissaoui, D.M., Coniglio, M., James, N.P., and Purser, B.H., 1986. Diagenesis of a Miocene reef-platform: Jebel Abu Shaar, Gulf of Suez, Egypt. In Schroeder, J.H., and Purser, B.H. (Eds.), Reef Diagenesis: New York (Springer-Verlag).

Al-Aasm, I.S., and Veizer, J., 1986. Diagenetic stabilization of aragonite and low-Mg Calcite, I. Trace elements in rudists. J. Sediment. Petrol., 56:138152.

Allan, J.R., and Matthews, R.K., 1982. Isotope signatures associated with early meteoric diagenesis. Sedimentology, 29:797-817.

Bergersen, D.D., 1993. Geology and geomorphology of Wodejebato (Sylvania) Guyot, Marshall Islands. In Pringle, M.S., Sager, W.W., Sliter, W.V., and Stein, S. (Eds.), The Mesozoic Pacific: Geology, Tectonics, and Volcanism. Geophys. Monogr., Am. Geophys. Union. 77:367-385.

Budd, D.A., 1988a. Aragonite-to-calcite transformation during fresh-water diagenesis of carbonates: insights from pore-water chemistry. Geol. Soc. Am. Bull., 100:1260-1270.

1988b. Petrographic products of freshwater diagenesis in Holocene ooid sands, Schooner Cays, Bahamas. Carbon. Evapor., 3:143-163.

Budd, D.A., and Land, L.S., 1990. Geochemical imprint of meteoric diagenesis in Holocene ooid sands, Schooner Cays, Bahamas: correlation of calcite cement geochemistry with extant groundwaters. J. Sediment. Petrol., 60:361-378

Dunham, R.J., 1971. Meniscus cement. In Bricker, O.P. (Ed.), Carbonate Cements: Baltimore (Johns Hopkins Press), 297-300.

Folk, R.L., 1965. Some aspects of recrystallization in ancient limestones. In Pray, L.C., and Murray, R.C. (Eds.), Dolomitization and Limestone Diagenesis. Spec. Publ.-Soc. Econ. Paleontol. Mineral., 13:28-62.

Freeman-Lynde, R.P., Fulker Whitley, K., and Lohmann, K.C., 1986. Deepmarine origin of equant spar cements in Bahama Escarpment limestones. J. Sediment. Petrol., 56:799-811.

Haq, B.U., Hardenbol, J., and Vail, P.R., 1987. Chronology of fluctuating sea levels since the Triassic. Science, 235:1156-1167.

James, N.P., and Choquette, P.W., 1990a. Limestones-the meteoric diagenetic environment. In McIlreath, I.A., and Morrow, D.W. (Eds.), Diagenesis. Geosci. Can., 4:35-73.

, 1990b. Limestones - the sea-floor diagenetic environment. In McIlreath, I.A., and Morrow, D.W. (Eds.), Diagenesis. Geosci. Can., 4:13-34.

Land, L.S., 1970. Phreatic vs. vadose meteoric diagenesis of limestones: evidence from a fossil water table. Sedimentology, 14:175-185.

Lincoln, J.M., 1990. Regional tectonic history and Cenozoic sea levels deduced from drowned carbonate banks and atoll stratigraphy in the Marshall Islands, West Central Pacific Ocean. [Ph.D. dissert.]. Northwestern Univ., Evanston, IL.

Lincoln, J.M., Pringle, M.S., and Premoli-Silva, 1., 1993. Early and Late Cretaceous volcanism and reef building in the Marshall Islands. In Pringle, M.S., Sager, W.W., Sliter, W.V., and Stein, S. (Eds.), The Mesozoic Pacific: Geology, Tectonics, and Volcanism. Geophys. Monogr., Am. Geophys. Union, 77:279-305.

Lincoln, J.M., and Schlanger, S.O., 1991 Atoll stratigraphy as a record of sea level change-problems and prospects. J. Geophys. Res., 96:6727-6752.

Lohmann, K.C., 1988. Geochemical patterns of meteoric diagenetic systems and their application to studies of paleokarst. In James, N.P., and Choquette, P.W. (Eds.), Paleokarst: New York (Springer-Verlag), 58-80.

Longman, M.W., 1980. Carbonate diagenetic textures from near-surface diagenetic environments. AAPG Bull., 64:461-487.

Ludwig, K.R., Halley, R.B., Simmons, K.R., and Peterman Z.E., 1988. Strontium-isotope stratigraphy of Enewetak Atoll. Geology, 16:173-177.

\footnotetext{
Abbreviations for names of organizations and publications in ODP reference lists follow the style given in Chemical Abstracts Service Source Index (published by American Chemical Society).
} 
Major, R.P., and Matthews, R.K., 1983. Isotopic composition of bank margin carbonates on Midway Atoll: amplitude constraint on post-early Miocene eustasy. Geology, 11:335-338.

Matthews, R.K., 1974. A process approach to diagenesis of reefs and reef associated limestones. In LaPorte, L.F. (Ed.), Reefs in Time and Space. Spec. Publ.-Soc. Econ. Paleontol. Mineral., 18:234-256.

McArthur, J.M., Kennedy, J.W., Chen, M., Thirlwall, M.F., and Gale, A.S., 1994. Strontium isotope stratigraphy for the Late Cretaceous time: direct numerical calibration of the $\mathrm{Sr}$ isotope curve based on the U.S. western interior. Palaeogeogr., Palaeoclimatol., Palaeoecol., 109:95-119.

McConnaughey, T., 1989. ${ }^{13} \mathrm{C}$ and ${ }^{18} \mathrm{O}$ isotopic disequilibrium in biological carbonates. I. Patterns. Geochim. Cosmochim. Acta, 53:151-162.

Ohde, S., and Elderfield, H., 1992. Strontium isotope stratigraphy of KitaDaito-Jima Atoll, North Philippine Sea: implications for Neogene sea-level change and tectonic history. Earth Planet. Sci. Lett., 113:473-486.

Premoli Silva, I., Haggerty, J., Rack, F., et al., 1993. Proc. ODP, Init. Repts, 144: College Station, TX (Ocean Drilling Program).

Quinn, T.M., 1991. Meteoric diagenesis of post-Miocene limestones on Enewetak Atoll. J. Sediment. Petrol., 61:681-703.

Quinn, T.M., Lohmann, K.C., and Halliday, A.N., 1991. Sr isotopic variation in shallow water carbonate sequences: stratigraphic, chronostratigraphic, and eustatic implications of the record at Enewetak Atoll. Paleoceanography, 6:371-385,

Richter, F.M., and DePaolo, D.J., 1988. Diagenesis and Sr isotope evolution of seawater using data from DSDP 590B and 575. Earth Planet. Sci. Lett, 90:382-394.

Saller, A.H., 1986. Radiaxial calcite in lower Miocene strata, subsurface Enewetak Atoll. J. Sediment. Petrol., 56:743-762.

Saller, A.H., and Koepnick, R.B., 1990. Eocene to early Miocene growth of Enewetak Atoll: insight from strontium isotope data. Geol. Soc. Am. Bull., 102:381-390.

Saller, A.H., and Moore, C.H., 1991. Geochemistry of meteoric calcite cements in some Pleistocene limestones. Sedimentology, 38:601-621.

1989. Meteoric diagenesis, marine diagenesis, and microporosity in Pleistocene and Oligocene limestones, Enewetak Atoll, Marshall Islands. Sediment. Geol., 63:253-272.
Schlanger, S.O., Campbell, J.F., and Jackson, M.W., 1987. Post-Eocene subsidence of the Marshall Islands recorded by drowned atolls on Harrie and Sylvania guyots. In Keating, B.H., Fryer, P., Batiza, R., and Boehlert, G.W. (Eds.), Seamounts, Islands, and Atolls. Geophys. Monogr., Am. Geophys. Union, 43:165-174.

Schlanger, S.O., and Duennebier, F.K., 1988. Marshall Islands Cruise Report, MW8805.

Schlanger, S.O., and Premoli Silva, I., 1986. Oligocene sea-level falls recorded in mid-Pacific atoll and archipelagic apron settings. Geology, 14:392-395.

Swart, P.K., Ruiz, J., and Holmes, C.W., 1987. Use of strontium isotopes to constrain the timing and mode of dolomitization of upper Cenozoic sediments in a core from San Salvador, Bahamas. Geology, 15:262-265.

Terry, R.D., and Chilingar, G.V., 1955. Summary of "Concerning some additional aids in studying sedimentary formations" by M.S. Shvetsov. $J$. Sediment. Petrol., 25:229-234.

Vahrenkamp, V.C., Swart, P.K., and Ruiz, J., 1988. Constraints and interpretation of ${ }^{87} \mathrm{Sr} /{ }^{86} \mathrm{Sr}$ ratios in Cenozoic dolomites. Geophys. Res. Lett., 15:385-388.

Wagner, P.D., and Matthews, R.K., 1982. Porosity preservation in the upper Smackover (Jurassic) carbonate grainstone, Walker Creek field, Arkansas: response of paleophreatic lenses to burial processes. J. Sediment. Petrol., 52:3-18.

Ward, W.C., Weidie, A.A., and Back, W., 1985. Geology and hydrology of the Yucatan and Quaternary geology of northeastern Yucatan Peninsula. New Orleans Geol. Soc.

Wilkinson, B.H., Smith, A.L., and Lohmann, K.C., 1985. Sparry calcite marine cement in Upper Jurassic limestones of southeastern Wyoming. Spec. Publ.-Soc. Econ. Paleontol. Mineral., 36:169-184.

Date of initial receipt: 31 January 1994

Date of acceptance: 15 September 1994

Ms 144SR-056 